\title{
Life-forms, cell-sizes and ecological guilds of diatoms in European rivers
}

\author{
F. Rimet ${ }^{(1,2) \star}, A$. Bouchez $z^{(1,2)}$
}

Received April 13, 2012

Revised May 25, 2012

Accepted May 28, 2012

Key-words: Bacillariophyta, biomonitoring, check-list, metric, river

\section{ABSTRACT}

Diatoms are a very diverse group of microalgae that encompass about 100000 taxa. This makes an excellent bioindicator especially of rivers. The majority of biotic indices based on diatoms are constructed on species pollution-sensitivities. Nevertheless, recent studies showed the interest to use complementary metrics for biomonitoring: life-forms, cell-sizes and ecological guilds. Unfortunately, taxa memberships to such metrics are scattered in numerous floras and papers. Therefore, studies using such metrics often referred to grey literature or home-made checklists. The objective of this paper is to make available to the scientific community an important check-list of taxa frequently observed in European rivers with their memberships to these metrics. After defining these metrics, 1115 taxa were codified using Biofresh and Omnidia codes in an Excel file. Metrics memberships were then explored in a taxonomical framework. It clearly appears that metrics memberships are determined by taxonomy. Lifeforms and cell sizes taxa memberships and their study in the framework of evolutionary history of diatoms is a field that is worth studying for a better understanding of diatoms ecology. Such inputs should be beneficial for the future improvement of diatom-based monitoring tools.

\section{RÉSUMÉ}

Formes de vie, tailles de cellule et guildes écologiques des diatomées des rivières européennes

\section{Mots-clés : Bacillariophyta, bioindication, liste, métrique, rivière}

Les diatomées sont un groupe très diversifié de microalgues, qui comprend plus de 100000 taxons. Cela en fait un excellent bioindicateur, en particulier des rivières. La majorité des indices biotiques basés sur les diatomées sont construits sur les polluo-sensibilités des espèces. Néanmoins, des études récentes ont montré l'intérêt d'utiliser des métriques complémentaires pour la bioindication : les formes de vie, les tailles de cellules et les guildes écologiques. Malheureusement, l'appartenance des taxons à ces différentes métriques est souvent dispersée dans de nombreux articles et ouvrages. De plus, les études utilisant de telles métriques font souvent référence à de la littérature grise et des listes non publiées. L'objectif de cet article est de rendre disponible à la communauté scientifique une importante liste de taxons fréquemment observés dans les rivières européennes avec leur appartenance à ces différentes métriques. Après avoir défini ces métriques, 1115 taxons ont été codifiés en utilisant les codes Biofresh et Omnidia dans un fichier Excel. L'appartenance aux métriques a été explorée dans un cadre

(1) INRA, UMR 0042 Carrtel, 75 avenue de Corzent, 74203 Thonon, France

(2) Université de Savoie, UMR CARRTEL, 74203 Thonon-les-Bains Cedex, France

* Corresponding author: frederic.rimet@thonon.inra.fr 
taxonomique. II apparaît clairement que l'appartenance des taxons aux métriques est déterminée par la taxonomie. L'appartenance aux formes de vie et aux tailles de cellules et leur étude dans le cadre de l'histoire de l'évolution des diatomées est un champ qui est utile à étudier pour une meilleure compréhension de l'écologie des diatomées. De tels apports devraient être bénéfiques pour l'amélioration future des outils de bioindication basés sur les diatomées.

\section{INTRODUCTION}

Diatoms are an extremely diverse phylum of microalgae encompassing about 100000 taxa (Mann and Droop, 1996). This diversity made diatoms an excellent bioindicator since nutrients and organic matter were demonstrated to control taxonomic composition, richness and diversity (e.g. Patrick, 1961; Lange-Bertalot, 1979). Their ubiquity is also a relevant advantage. Moreover, benthic diatoms constitute a major part of the biomass in temperate rivers (e.g. Smol and Stoermer, 2010). This lead several authors to develop autecological indices on the basis of ecological preferences of diatom taxa (Butcher, 1947; Fjerdingstad, 1950; Hustedt, 1957; Zelinka and Marvan, 1961). Diatoms are now worldwide used to assess rivers ecological quality (e.g. Coste et al., 1991; Lobo et al., 1995; Kelly et al., 1998; Chessman et al., 1999; Rimet, 2012) beside macroinvertebrates, fish, phytoplankton and macrophytes. Most of these indices are based on the formula of Zelinka and Marvan (1961). This formula is typically a weighted average equation implying a unimodal response curve, even if a large majority of diatom species do not show such trend as was demonstrated in the USA (Potapova et al., 2004). Field sampling, diatom preparation and counting are subject to frequent standardization procedures at European level since the end of the nineties (Kelly et al., 1998; Afnor, 2000, 2003, 2004, 2007). Basically, diatoms are scraped from inert hard substratum (5 stones in the French standard) selected in lotic zones of rivers. Then the sample is fixed in $4 \%$ formaldehyde. In laboratory, the diatom valves are cleaned using $30 \% \mathrm{H}_{2} \mathrm{O}_{2}$ and $\mathrm{HCl}$. Clean valves are mounted in a resin (Naphrax $\left.{ }^{\odot}\right)$. At least 400 valves from each sample are counted and identified using a light microscope (1000 $\times$ magnification). The abundances of all observed taxa are expressed as relative counts. Identifications are carried out using Krammer and Lange-Bertalot (1986, 1988, 1991a, 1991b) and other specialized books to species and sub-species level.

Most of the existing biotic indices for diatoms are based on species sensitivity, because authors of diatom indices classically consider that the most precise determination level is the most effective choice for diatom biomonitoring. This is done regardless such indices have to be applied on large geographical scale by a multitude of people who do not possess necessarily the same identification skills. For diatoms it was shown that bioassessment precision gain to determine diatoms at species level instead of genus or family level was very small (Rimet and Bouchez, 2012). Similarly some authors showed for macroinvertebrates that there was no clear increase of the assessment power when taxonomic resolution increased (Jones, 2008).

Moreover, diatom species (or infra-specific level) identifications can be challenging because of their tremendous diversity and because of the increasing interest in taxonomy leading to the description of numerous new species and to incessant taxonomic arrangements. Several hundreds of taxa are discovered and described each year according to the Catalogue of Diatom Names of the California Academy of Sciences (compiled by E. Fourtanier and J.P. Kociolek). Untill now, these new taxa are described on the basis of frustule morphology and split species complexes into numerous species with restricted range of morphological variations. Moreover, recent studies based on phylogenetic and mating techniques and carried out on species complexes such as Nitzschia palea (Trobajo et al., 2009), Sellaphora pupula (Mann et al., 2004; Evans et al., 2008), Navicula cryptocephala (Poulickova et al., 2010), N. phylepta 


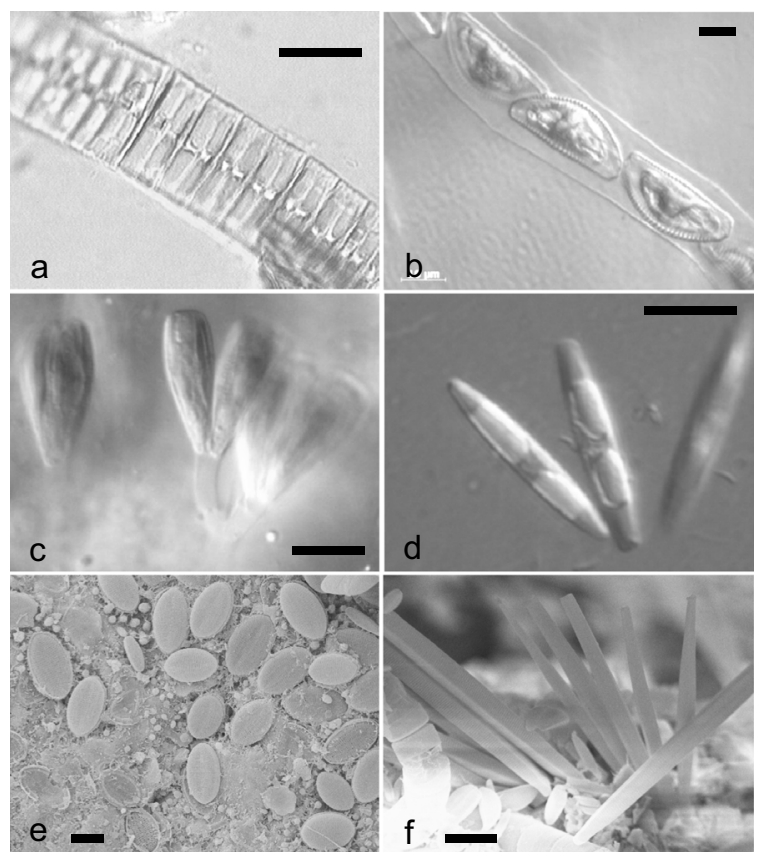

\section{Figure 1}

Examples of diatom life-forms. (a) Ribbon colony with Fragilaria capucina var. vaucheriae (from the Thonon Culture Collection, culture TCC372), (b) mucous tubules with Encyonema minutum (live sample from lake Geneva shore, 2011), (c) stalks with Gomphonema sp. (live sample from lake Geneva shore, 2012), (d) fast-moving diatom as Nitzschia palea (culture TCC764), (e) prostrated Cocconeis placentula var. euglypta (dehydrated biofilms from Rollingerbaach river, Luxembourg, 2003), (f) rosette of Ulnaria (dehydrated biofilms from Rollingerbaach river, Luxembourg, 2003). Black bar in each photo corresponds to $10 \mu \mathrm{m}$.

(Vanelslander et al., 2009), Gomphonema parvulum (Kermarrec et al., 2012) revealed an unexpected cryptic diversity which is sometimes difficult to relate to particular environmental parameters or geographical distributional patterns. These studies should increase the estimated number of potential diatom taxa existing on Earth. Besides this, an amnesic behavior or an incomplete knowledge of literature of taxonomist can also artificially conduct to the creation of already described species, for instance Cyclotella operculata f. minuta described by Grunow (in Van Heurck, 1882) and more recently re-described by Druart and Straub as C. costei (Druart and Straub, 1988). Two years later Hakansson and Carter (1990) introduced another conspecific taxon (C. cyclopuncta). It is frequent that a species described by scientists in one part of the world is also recorded and described by scientists in another. For these reasons, diatom taxonomy can be challenging to follow.

Finally, from a financial point of view, determining diatoms to species level takes much more time than to genus level and cost depends on time expended for the identification. Some authors (e.g. Zampella et al., 2007) think that large number of diatom species and identifications' difficulties limit their use in routine, and identification mistakes are numerous at species level. But these ideas are not unanimous, and other authors (e.g. Ponader and Potapova, 2007) believe that it is necessary to have precise determination for a good environmental assessment.

Other metrics, than specific sensitivities, can be used for ecological studies and bioassessment purposes. This is the case of metrics such as life-forms (Figure 1), cell sizes (or biovolumes) and ecological guilds. Relationships between the abundances of such life-forms and nutrients were established in experimental contexts (Hoagland et al., 1982; Pringle, 1990) and gave satisfactory results in large scale studies to assess nutrient and global pollution (e.g. Fore and Grafe, 2002; Berthon et al., 2011). Some of these relationships are proposed for bioassessment tools (Barbour et al., 1999). This is the case of abundance of motile diatoms 
to assess siltation (Bahls, 1993; Battegazzore et al., 2004; Tudesque et al. 2012). Diatom cell size is also a response which can be related to the available resources (Finkel et al., 2009). Such metrics were tested in Canadian rivers (Lavoie et al., 2010) but did not gave satisfactory results for phosphorus assessment. Nevertheless, the relationship between cell-size/species richness is related to maximum nutrient uptake (Passy, 2007b).

The diversity of these life-forms can be regrouped in larger groups, so called ecological guilds. These can be defined as a group of species - equivalent to functional groups in phytoplankton (e.g. Padisak et al., 2009) - which live in the same environment, but may have adapted differently to abiotic factors. For instance to resist sedimentation in plankton, diatoms display various life-forms (long filaments, stellate colonies, threads of polysaccharides, etc.). These ecological guilds gather taxa belongings or not to the same taxonomic clade. The interest to work on such ecological guilds is that the links established with environmental factors can be stronger than those established with single species.

Passy (2007a) defined guilds classification: the 'low-profile' guild which encompasses species of short stature including prostrate, adnate, and erect diatoms. Such group is resistant to physical disturbances (water turbulence) and do not tolerate nutrient enrichment. The "highprofile" guild comprises large species, or those which tend to form colonies (e.g. tubeforming, filamentous, branched diatoms). Such group does not resist turbulence but is favored by nutrient enrichment. The 'motile' guild consists of fast-moving species (e.g. Navicula, Nitzschia). For this last group Passy (2007a) hypothesized that it was adapted to turbulent environment and to high nutrients concentrations. Additionally, the high profile guild showed to be sensitive to herbicide contamination in lotic mesocosms and showed a decrease abundance when pesticide concentration increased (Rimet and Bouchez, 2011).

Unfortunately, classifications giving for each species its life-forms, size classes and ecological guilds membership, are often reduced to a small number of taxa (e.g. Passy, 2007a), or to grey literature. For instance life-forms classes in Fore and Grafe (2002) and in Fore (2002) refer to "R.J. Stevenson, personal communication" and biovolumes in Passy (2007b) refer to "Biovolume data for the diatom species were obtained from the NAWQA data set".

The objective of this paper is to make available to the scientific community an important check-list of taxa frequently recorded in European rivers with their memberships to life-forms, size classes and ecological guilds. Strictly marine taxa were not taken into account. We also wanted to enable an easy search, thanks to the species codes used internationally such as the Omnidia (Lecointe et al., 1993, http://omnidia.free.fr) and the speciesID codes available in the www.freshwaterecology.info website.

Finally, we explored and discussed the life-forms, cell-sizes classes and ecological guilds taxa memberships in a taxonomical framework.

\section{METHODOLOGY}

\section{> DIATOM LIFE-FORMS}

Even if diatoms are basically unicellular algae, they exhibit an important diversity of life-forms, and many of them can form colonies. Taxa can even present several successive life-forms during their life-cycle. This is the case for instance with Cymbella species which can be unicellular and free moving at a time, and attached to a peduncle and then immobile at another time. For that reason, in our classification, a single taxon can be classified into several life-forms. To assign each taxon to the diatom life-forms, we referred to several papers and books, which are given for each taxon in Appendix 1.

Based on (Round et al., 1990), we propose the following classification of life-forms:

1. Solitary cells:

If diatoms are solitary cells, they can fit in the following forms:

- Not attached: diatoms are floating (e.g., Centric diatoms in plankton) or free moving (e.g., free moving cells of Nitzschia or Navicula). 
- Attached: diatom can be attached to substrates according to different modes:

- Adnate: cells are firmly attached by their valve face (e.g., Cocconeis spp.) or by their girdle view (e.g., Eunotia spp.).

- Mucilage pad: cells produce mucilage on a pole that stick to substrate (e.g., Diatoma spp., Ulnaria spp.)

- Mucilage stalk: through apical pore fields cells produce a stalk that sticks to the substrate. The stalk can be simple, that is linked to one cell (e.g., Achnanthidium spp.) or can be linked to several cells (see arbuscular colonies of Gomphonema spp.).

2. Colonies:

The diversity of type of colonies is important but can be regrouped in the following classes for freshwater taxa:

- Chain colonies: centric cells are juxtaposed by their valves. Cells can be linked by spines (Aulacoseira spp.) or by granules (Melosira varians). In some cases (Cyclotella spp., Thalassiosira spp.) cells do not touch, and are simply held together by threads of polysaccharides. But these taxa are mostly unicellular in turbulent waters as it is the case in rivers, and therefore were not considered in this life-form.

- Ribbon colonies: some pennate diatoms can be juxtaposed by their valves, and linked by spines (e.g., Fragilaria capucina var. vaucheriae). They can be also adherent by mucilage excretions on their whole valve face (Fragilariopsis spp., also observed one time on Nitzschia sp. in cultures, Kermarrec com. pers.).

- Zig-zag colonies: pennate cells are connected by mucilage at their opposed poles (Diatoma spp.).

- Rosette colonies: pennate cells produce a short stalk at one pole that sticks to the substrate. After several cell divisions, they produce colonies that resemble fan/rosette (e.g., Ulnaria spp.).

- Star colonies: pennate cells are connected by mucilage at their neighbor poles (e.g., Asterionella formosa, Nitzschia fruticosa).

- Arbuscular colonies: stalks are produced at one or either pole. The stalks diverge from each cell and form branching colonies (e.g., Gomphonema spp., Cymbella spp., Rhoicosphaenia abbreviata).

- Mucous tubule colonies: several diatom genera form tubes (e.g., Encyonema spp., Frustulia spp., Berkeleya spp., Parlibellus spp.), and files of cells are moving inside.

- Beside these life-forms classes, additional information was given. First, mobility of the taxa was given (this character was determined by the presence or absence of a raphe system). Second, taxa considered as pioneers in rivers are given. They correspond to small adnate taxa of the Achnanthidium minutissimum species complex and to Amphora pediculus and A. inariensis. Third, some Omnidia codes correspond to teratological forms of particular taxa, therefore, we gave this additional information.

For each taxon, its life-forms memberships are given in Appendix 1.

\section{$>$ CELL SIZES}

Cells sizes were taken from the literature, mostly from the Krammer and Lange-Bertalot (1986, 1988, 1991a, 1991b) floras but also from the Iconographia Diatomologica, Bibliotheca Diatomologica, and Diatoms of Europe series. For each taxon, the reference used to determine the dimensions are given in Appendix 1. The length, width averages (average between minimum and maximum values) are given in Appendix 1 . The thickness is usually not given in the floras. This parameter was estimated after expert judgment. In some cases, the values already in the Omnidia software (Lecointe et al., 1993) were given; in such case it is referred to "Omnidia" in Appendix 1.

Based on these measures, a biovolume is calculated following the formulas suggested in (Hillebrand et al., 1999). Depending on the shape of the taxon, one of these formulas was used and a codification is given in Appendix 1: elliptic cylinder (ellcyl), rhomboid prism (rhp), box 
(box), sphere (sphe), tube (tub). We used also third of sphere for the case of Amphora species (sphe/3). In the case taxa did not match exactly a geometrical shape, the nearest shape was chosen, and a factor corresponding to the ratio between taxa shape and exact geometrical shape is multipled to the formula of the geometrical shape. In other cases, the values already in the Omnidia software (Lecointe et al., 1993) were given (noted Omnidia in Appendix 1). Taxa were afterward classified into 5 classes of biovolumes (in $\mu \mathrm{m}^{3}$ ) with boundaries following a logarithmic evolution: $0<$ class $1<100 \leqslant$ class $2<300 \leqslant$ class $3<600 \leqslant$ class $4<1500 \leqslant$ class 5.

\section{$>$ ECOLOGICAL GUILDS}

An ecological guild is a group of taxa belonging to the same taxonomic or functional group that exploit the same resources (e.g., Carrère and Bloor, 2009). Taxa of an ecological guild co-exist in the same environment and can display different adaptations to the same abiotic factors.

In her paper, Passy (2007a) proposed a guild classification based on the potential of species to use nutrient resources and to resist to physical perturbation. Three guilds were proposed. In this paper, we proposed modifications for a new guild classification.

First, we added an ecological guild, corresponding to planktic species. In the classification of Passy (2007a), solitary centrics (e.g., Cyclotella spp., Stephanodiscus spp.) are included in the low profile guild. Our hypothesis is that such taxa do not belong to this ecological guild because they are not adapted to resist to strong physical constrains such as Amphora, Cocconeis which have a prostrated habit. They are on the contrary absent in such kind of environments. Therefore an additional guild was defined, the 'planktic' guild. It corresponds to taxa adapted to lentic environments with morphological adaptations that enable them resisting to sedimentation (e.g., Nitzs chia acicularis, Cyclotella spp., Ulnaria angustissima etc.). Filamentous diatoms which were included in the high profile guild were also transferred in the planktic guild (Aulacoseira, Skeletonema). Nevertheless, the filamentous species Melosira varians and Ellerbeckia arenaria were kept in the high-profile guild because they are clearly benthic diatoms, rarely found in planktic habitats.

Second, for the low profile guild, we kept the definition of Passy (2007a), i.e. "species of short stature, including prostrate (adhering to the substrate with the entire valve surface), adnate (apically attached but parallel to the substrate), erect (apically attached but perpendicular to the substrate)", "and slow moving species" (e.g., Achnanthes, Achnanthidium, Amphora, Cocconeis, Cymbella, Meridion, Opephora, and Reimeria). Such taxa are adapted to high current velocities and to low nutrients concentrations. We excluded planktic species from this guild. Moreover, we excluded from the low profile guild all taxa presenting the largest size class (over $1500 \mathrm{um}^{3}$ ) and placed them in the high profile guild. Our hypothesis was that such taxa could not resist to high current velocities. Therefore, large Cymbella (e.g., C. lanceolata), Cymbopleura, Eucocconeis (E. flexella) and Achnanthes (A. brevipes) were placed in the high profile guild. We nevertheless made an exception for large taxa belonging to Amphora and Cocconeis genera because they show a prostrated habit which enable them to resist to high current velocities.

Third, for the high profile guild, the definition of Passy (2007a) was kept: "species of tall stature, including erect, filamentous, branched, chain-forming, tube-forming, stalked, and colonial centrics from the following genera: Diatoma, Ellerbeckia, Eunotia, Fragilaria, Gomphoneis, Gomphonema, Melosira (Melosira varians), and Synedra". This guild is adapted to high nutrients concentrations and low current velocities. Tubeforming diatom such as Amphipleura, Berkeleya, Encyonema, Frustulia and Parlibellus were included in this guild. We added moreover large size taxa $\left(>1500 \mu \mathrm{m}^{3}\right)$ such as Cymbella, Cymbopleura, Eucocconeis and Achnanthes, and filamentous benthic taxa such as Melosira varians and Ellerbeckia arenaria.

Fourth, for the motile guild, we kept the definition of Passy (2007a) that include "fast moving species from the genera Navicula, Nitzschia, Sellaphora, and Surirella". Passy hypothesized 


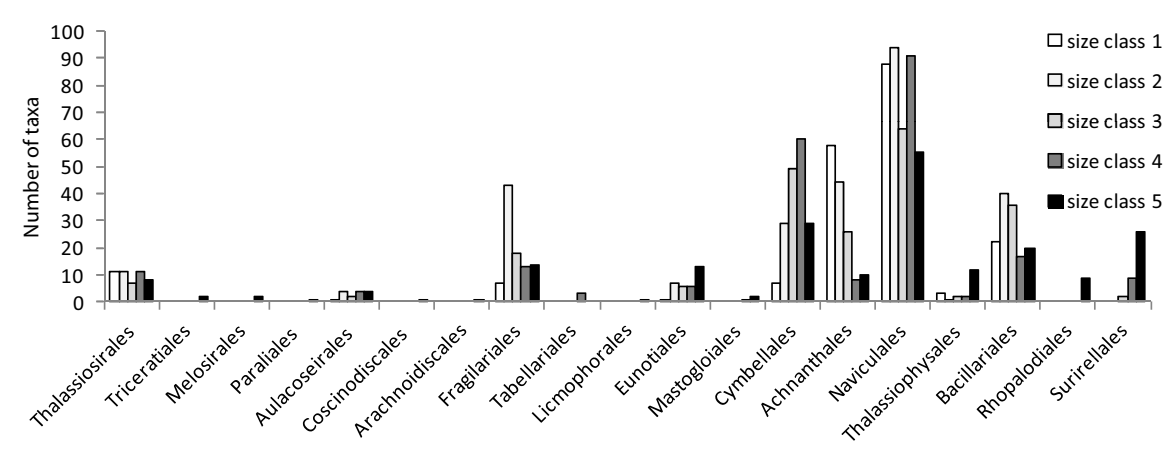

\section{Figure 2}

Number of taxa in each size class for each order.

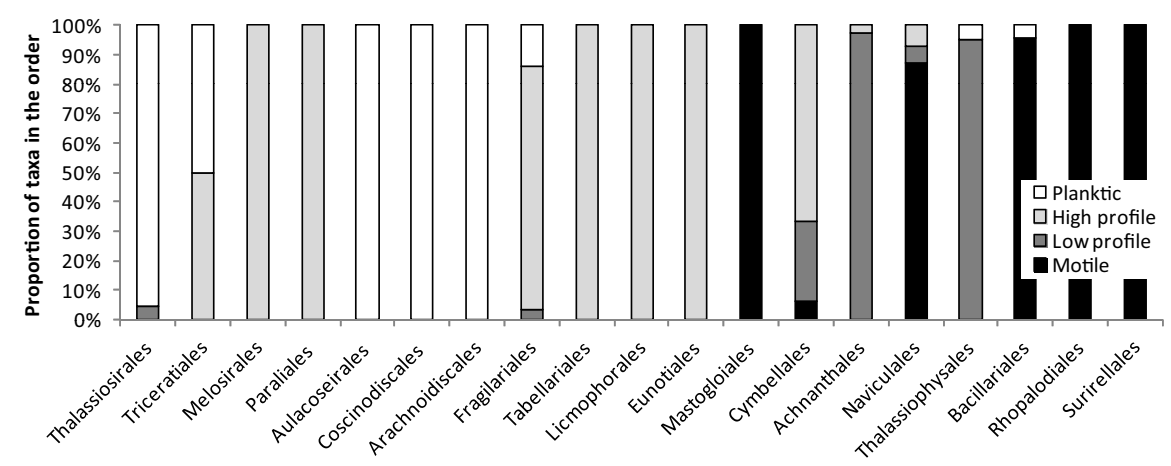

Figure 3

Proportions of taxa in each guild for each order.

that this guild was adapted to relatively high current velocities and high nutrients concentrations, but her results showed that they were not tolerant to high current velocities and tolerant to high nutrient concentrations. Several other genera belonging to the Bacillariales, Mastogloiales, Naviculales, Rhopalodiales, and Surirellales were added.

\section{> LIFE-FORMS, SIZE-CLASSES, ECOLOGICAL GUILDS, AND TAXONOMY}

Taxonomy of each taxon is given from division to infra-specific level according to algaebase (Guiry and Guiry, 2012) in Appendix 1. The memberships of taxa to the different life-forms, size-classes and ecological guilds were explored with simple descriptive statistics. We also used a diversity index (Weaver and Shannon, 1949) to assess the diversity of life-forms displayed by taxa inside each order.

\section{RESULTS}

A total of 1115 taxa is codified in Appendix 1. These taxa were encountered during surveys carried out in the framework of the river monitoring of two large eastern basins in France, the Rhin-Meuse and the Rhône-Mediterranean basins (Rimet and Bouchez, 2012). The highest taxonomic richness is recorded in the Naviculales, then in the Cymbellales, Achnanthales, and Bacillariales orders, all of them included in the Bacillariophyceae class (Figure 2). Taxa gathered in the Coscinodiscophyceae and Mediophyceae classes, and which are mostly belonging to the planktic guild (Figure 3), are less represented. This can probably be explained by the field work and the sampling protocol which is unfavorable to the sampling of such guild, because composed by rivers and benthic samples. 


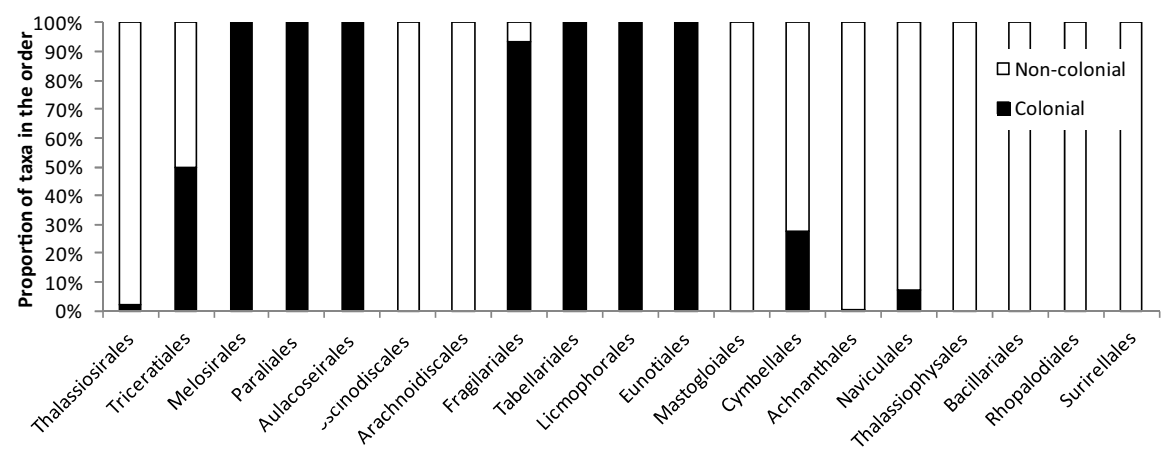

Figure 4

Proportions of colonial and non-colonial taxa for each order.

Depending on the order considered, size classes are not represented in the same proportions (Figure 2). For instance, most of the taxa of the Achnanthales are small sized, and belong to the low profile guild (Figure 3). On the contrary, all the taxa of the Surirellales display large sizes. Similarly, taxa of the Thalassiophysales are also mostly of large size, even if the most often encountered taxa in rivers (Amphora pediculus, $A$. inariensis) are small sized. Taxa of the Eunotiales are rarely belonging to the smallest size class, but mostly to medium to large sizes. Taxa of the Cymbellales are mostly of medium sizes, as those of the Bacillariales. But, for other orders such as Naviculales and Thalassiosirales, the number of taxa in the five size classes is homogeneous.

Repartition of ecological guilds in the different orders shows that their occurrence is related to high taxonomical levels (Figure 3). Indeed, an average of $96 \%$ of taxa of the Mastogloiales, Naviculales, Bacillariales, Rhopalodiales, and Surirellales are members of the motile guild. In the same way, an average of $96 \%$ of the taxa of the Achnanthales and the Thalassiophysales belongs to the low-profile guild. Taxa of the Melosirales, Tabellariales, Eunotiales are all members of the high-profile guild. The Cymbellales order is the only one showing an important diversity of ecological guilds (66\% of high-profile, $27 \%$ of low-profile and $6 \%$ of motile).

Proportion of taxa presenting colonial forms is strongly related to some particular orders and even classes (Figure 4): a large majority of taxa belonging to the Coscinodiscophyceae class (Aulacoseirales, Melosirales, Paraliales) are colonial and in particular are filamentous. Orders like Fragilariales, Tabellariales, Eunotiales also present an important proportion of colonial taxa (mostly ribbons and zig-zag colonies).

Most of the orders present a single kind of life-forms as shown by their life-forms diversity (Figure 5). For instance Thalassiosirales, Mastogloiales, Bacillariales, Surirellales, Rhopalodiales only encompass single celled taxa, Aulacoseirales encompass only filamentous taxa. On the other hand, some orders display high life-form diversities, such as Fragilariales which can be ribbon, stellate, rosette or zig-zag colonies, or Cymbellales which can be stalked, in mucilage tubules or arbuscular colonies. Life-form diversity of Triceratiales must be moderated because this order encompasses only two species.

\section{DISCUSSION}

Analysis of taxa memberships to life-forms, ecological guilds and size-classes clearly shows important taxonomical structures. We observed for instance that ecological guild memberships are strongly dependent on the taxonomy, at least at the Order level. For instance, the low-profile guild is restricted to the Bacillariophyceae class, and more precisely to the Achnanthales, Thalassiophysales orders and to some Cymbellales. Similarly, the planktic guild is essentially present in the Mediophyceae and Coscinodiscophyceae classes. The same for the motile guild, which is present only in the Bacillariophyceae class, with all the taxa of the Mastogloiales, Bacillariales, Rhopalodiales and Surirellales orders which belong 
Life-forms diversity $\left(\mathrm{H}^{\prime}\right)$

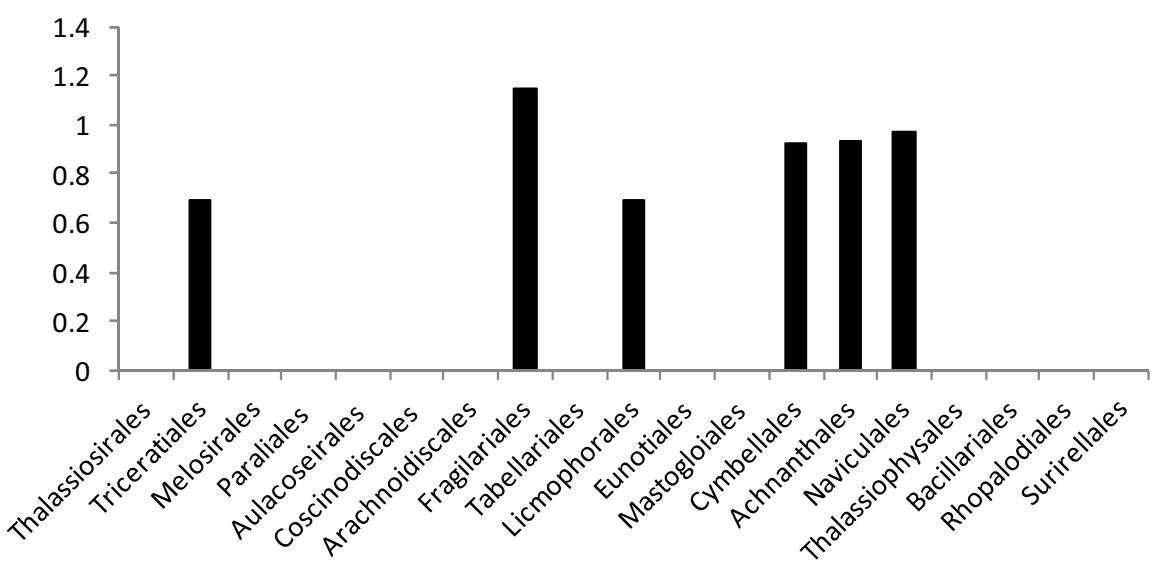

Figure 5

Life-forms diversity for each order. Diversity was assessed by mean of the Shannon Index.

to this guild. In the same way, we observed that the taxa membership to size-classes are strongly structured by Order. For instance taxa of the Achnanthales are mostly of small sizes, this can be related to their ecology: most of these taxa are characteristic of fast-flowing rivers with low nutrients levels (Rumeau and Coste, 1988; Leira et al., 2009). On the contrary, taxa of the Surirellales are mostly large size diatoms, such taxa are mostly epipelic diatoms (Round et al., 1990), loosely attached to the sediment and, which are living in lentic habitats. This can explain their preferably large sizes.

As underlined in Round et al. (1990), life-forms of diatoms have been subjected to strong selection. They are responses to attachment, light and nutrient capture, sinking rate, habitat selection. This would explain why we observed such strong differences between Orders in terms of taxa memberships. We can state that the largest diversity of life-forms among freshwater diatoms is in the Bacillariophyceae which are mostly benthic taxa. This is also stated by Julius and Theriot (2010) and they explain this high diversity by the necessity of benthic diatoms to adapt to a variety of substrates (sediments, rocks, plants, animals etc.), physical disturbance, grazing pressure etc. For instance, variation in life-forms is directly impacted by current velocity (Tuji, 2000), and these variations change the availability of cells for grazers (Julius and Theriot, 2010): for instance ribbon colonies are much easily grazed than small adnate diatoms. This strengthens the idea that life-forms are at the cross-roads of several kinds of selective pressures.

\section{CONCLUSIONS}

Life-forms, cell-sizes are responses to the evolutionary history of diatoms when they are subjected to important environmental barriers and strong competitions with other organisms. In some cases, such stressors made them radiate and develop new life-forms. But in many cases life-forms seem to have evolved multiple times. This is the case for instance with stalked diatoms which are the dominant taxa in several orders (Achnanthales, Cymbellales, Licmophorales). This is also the case for mucous-tubule diatoms which are present in several orders, but they are more restricted to particular genera (Amphipleura, Berkeleya, Delicata, Encyonema, Frustulia, Muelleria, Parlibellus). This is also the case for stellate colonies which are more restricted to particular species (Asterionella formosa, Nitzschia fructicosa, and several Fragilaria species such as $F$. tenera var. lemanensis). It seems therefore that depending on the life-form considered, they emerged at different evolutionary time scales. 
Grouping species into life-forms and cell-sizes, which are themselves regrouped into ecological guilds can clearly strengthen relations with certain environmental stressors when compared to basic species data. This was demonstrated for current velocity (Passy and Larson, 2011), nutrients (Berthon et al., 2011) and micropollutants (Rimet and Bouchez, 2011). Moreover, life-forms, cell-sizes taxa memberships and their study in the framework of evolutionary history of diatoms is clearly a field that is worth studying for a better understanding of diatoms ecology. Such inputs should be beneficial for the future of diatom bioassessment.

\section{ACKNOWLEDGEMENTS}

Vincent Berthon is thanked for his help in managing the databases. This paper was partly financed by the ONEMA (Office National de l'Eau et des Milieux Aquatiques).

\section{REFERENCES}

Afnor, 2000. Norme Française NF T 90-354 : Qualité de l'eau - Détermination de I'Indice Biologique Diatomées (IBD). Afnor, 1-53.

Afnor, 2003. NF EN 13946 : Qualité de l'eau - Guide pour l'échantillonnage en routine et le prétraitement des diatomées benthiques de rivières. Afnor, 1-18.

Afnor, 2004. NF EN 14407 : Qualité de l'eau - Guide pour l'identification et le dénombrement des échantillons de diatomées benthiques de rivières, et leur interprétation. Afnor, 1-13.

Afnor, 2007. NF T90-354 : Qualité de l'eau - Détermination de I'Indice Biologique Diatomées (IBD). Afnor, 1-79.

Bahls L.L., 1993. Periphyton bioassessment methods for Montana streams. Water Quality Bureau, 1-23.

Barbour M.T., Gerritsen J., Snyder B.D. and Stribling J.B., 1999. Rapid bioassessment protocols for use in streams and wadeable rivers: periphyton, benthic macroinvertebrates and fish, 2nd edition, US Environmental Protection Agency, Office of Water, Washington, DC, $1 \mathrm{p}$.

Battegazzore M., Morosi A., Gallino B. and Fenoglio S., 2004. Environmental quality evaluation of Alpine springs in NW Italy using benthic diatoms. Diatom Res., 19, 149-165.

Berthon V., Bouchez A. and Rimet F., 2011. Use of diatom life-forms and ecological guilds to assess pollution in rivers: case study of south-eastern french rivers. Hydrobiologia, 673, 259-271.

Butcher R. W., 1947. Studies in the ecology of rivers. IV. The algae of organically enriched water. J. Ecol., 35, 186-191.

Carrère P. and Bloor J.M.G., 2009. Lexique thématique à l'usage des techniciens en écologie, INRA, EFPA, Unité de Recherche sur l'Ecosystème Prairial, 234 av. du Brezet, 63100 Clermont-Ferrand, France, $7 \mathrm{p}$.

Chessman B., Growns I., Currey J. and Plunkett-Cole N., 1999. Predicting diatom communities at the genus level for the rapid biological assessment of rivers. Freshwater Biol., 41, 317-331.

Coste M., Bosca C. and Dauta A., 1991. Use of algae for monitoring rivers in France. In: Whitton B.A., Rott E. and Fridriech G. (eds.), Institut für Botanik, Universitat Innsbruck, 75-83.

Druart J.C. and Straub F., 1988. Description de deux nouvelles Cyclotelles (Bacillariophyceae) de milieux alcalins et eutrophes: Cyclotella costei nov. sp. et Cyclotella wuetrichiana nov. sp. Schweizererische Zeitschrift für Hydrobiologie, 50, 182-188.

Evans K.M., Wortley A.H., Simpson G.E., Chepurnov V.A. and Mann D.G., 2008. A molecular systematic approach to explore diversity within the Sellaphora pupula species complex (bacillariophyta). J. Phycol., 44, 215-231.

Finkel Z.V., Vaillancourt C.J., Irwin A.J., Reavie E.D. and Smol J.P., 2009. Environmental control of diatom community size structure varies across aquatic ecosystems. Proc. R. Soc. B, 276, 1627-1634.

Fjerdingstad E., 1950. The microflora of the river Molleaa with special reference to the relation of benthic algae to pollution. Folia Limnol. Scand., 5, 1-123.

Fore L.S., 2002. Evaluating the biological condition of Bellevue streams using invertebrates and diatoms, Statistical Design, 1-21. 
Fore L.S. and Grafe C., 2002. Using diatoms to assess the biological condition of large rivers in Idaho (USA). Freshwater Biol., 47, 2015-2037.

Guiry M.D. and Guiry G.M., 2012. AlgaeBase, World-wide electronic publication, National University of Ireland, Galway, http://www.algaebase.org; searched on 29 March 2012.

Hakansson, H. and Carter K.B., 1990. An interpretation of Hustedt's terms "Schattenlinie", "Perlenreihe" and "Höcker" Using Specimens of the Cyclotella radiosa-complex, C. distinguenda Hust., and C. cyclopuncta nov. sp. J. lowa Acad. Sci., 97, 153-156.

Hillebrand H., Durselen C.D., Kirschtel D., Pollingher U. and Zohary T., 1999. Biovolume calculation for pelagic and benthic microalgae. J. Phycol., 35, 403-424.

Hoagland K.D., Roemer S.C. and Rosowski J.R., 1982. Colonization and community structure of two periphyton assemblages, with emphasis on the diatoms (Bacillariophyceae). Am. J. Bot., 69, 188213.

Hustedt F., 1957. Die Diatomeenflora des Flusssystems der Weser im Gebiet der Hansestadt Bremen. Abhandlungen naturwissenschaftlichen Verein zu Bremen, 34, 181-440.

Jones F.C., 2008. Taxonomic sufficiency: The influence of taxonomic resolution on freshwater bioassessments using benthic macroinvertebrates. Environ. Rev., 16, 45-69.

Julius M.L. and Theriot E.C., 2010. The Diatoms: a primer. In: Smol J.P. and Stoermer E.F. (eds.), The diatoms: applications for the environmental and earth sciences, 2nd edition, Cambridge University Press, 8-22.

Kelly M.G., Cazaubon A., Coring E., Dell'Uomo A., Ector L., Goldsmith B., Guasch H., Hürlimann J., Jarlman A., Kawecka B., Kwandrans J., Laugaste R., Lindstrom E.A., Leitao M., Marvan P., Padisak J., Pipp E., Prygiel J., Rott E., Sabater S., Van Dam H. and Vizinet J., 1998. Recommendations for the routine sampling of diatoms for water qualtiy assessments in Europe. J. Appl. Phycol., 10, 215-224.

Kermarrec L., Bouchez A., Rimet F. and Humbert J.F., 2012. Using a polyphasic approach to explore the diversity and geographical distribution of the Gomphonema parvulum (Kützing) Kützing complex (Bacillariophyta). Eur. J. Phycol. 44, 567-577.

Krammer K. and Lange-Bertalot H., 1986. Bacillariophyceae 1. Teil: Naviculaceae. In: Ettl H., Gerloff J., Heynig H. and Mollenhauer D. (eds.), Gustav Fischer Verlag, Stuttgart, 876 p.

Krammer K. and Lange-Bertalot H., 1988. Bacillariophyceae 2. Teil: Bacillariaceae, Epithemiaceae, Surirellaceae. In: Ettl H., Gerloff J., Heynig H., and Mollenhauer D. (eds.), Gustav Fischer Verlag, Stuttgart, $610 \mathrm{p}$.

Krammer K. and Lange-Bertalot H., 1991a. Bacillariophyceae 3. Teil: Centrales, Fragilariaceae, Eunotiaceae. In: Ettl H., Gerloff J., Heynig H. and Mollenhauer D. (eds.), Gustav Fischer Verlag, Stuttgart, $598 \mathrm{p}$.

Krammer K. and Lange-Bertalot H., 1991b. Bacillariophyceae 4. Teil: Achnanthaceae, Kritische Ergänzungen zu Navicula (Lineolatae) und Gomphonema. Gesamtliteraturverzeichnis Teil 4. In: Ettl H., Gerloff J., Heynig H. and Mollenhauer D. (eds.), Gustav Fischer Verlag, Stuttgart, 437 p.

Lange-Bertalot H., 1979. Pollution tolerance of diatoms as a criterion for water quality estimation. Nova Hedwig., 64, 285-304.

Lavoie I., Lento J. and Morin A., 2010. Inadequacy of size distributions of stream benthic diatoms for environmental monitoring. J. N. Am. Benthol. Soc., 29, 586-601.

Lecointe C., Coste M. and Prygiel J., 1993. "Omnidia": software for taxonomy, calculation of diatom indices and inventories managment. Hydrobiologia, 269/270, 509-513.

Leira M., Chen G., Dalton C., Irvine K.N. and Taylor D.H., 2009. Patterns in freshwater diatom taxonomic distinctness along an eutrophication gradient. Freshwater Biol., 54, 1-14.

Lobo E., Katoh K. and Aruga Y., 1995. Response of epilithic diatom assemblages to water pollution in rivers in the Tokyo Metropolitan area, Japan. Freshwater Biol., 34, 191-204.

Mann D.G. and Droop S.J.M., 1996. Biodiversity, biogeography and conservation of diatoms. Hydrobiologia, 336, 19-32.

Mann D.G., McDonald S.M., Bayer M.M., Droop S.J.M., Chepurnov V.A., Loke R.E., Ciobanu A. and du Buf J.M.H., 2004. The Sellaphora pupula species complex (Bacillariophyceae): morphometric analysis, ultrastructure and mating data provide evidence for five new species. Phycologia, 43, 459-482. 
Padisak J., Crossetti L.O. and Naselli-Flores L., 2009. Use and misuse in the application of the phytoplankton functional classification: a critical review with updates. Hydrobiologia, 621, 1-19.

Passy S.I., 2007a. Diatom ecological guilds display distinct and predictable behavior along nutrient and disturbance gradients in running waters. Aquat. Bot., 86, 171-178.

Passy S.I., 2007b. Differential cell size optimization strategies produce distinct diatom richness-body size relationships in stream benthos and plankton. J. Ecol., 95, 745-754.

Passy S.I. and Larson C.A., 2011. Succession in stream biofilms is an environmentally driven gradient of stress tolerance. Microb. Ecol., 62, 414-424.

Patrick R., 1961. A study of the number and kinds of species found in rivers of the Eastern Unisted States. Proc. Acad. Natl. Sci. Phila., 113, 215-258.

Ponader K.C. and Potapova M.G., 2007. Diatoms from the genus Achnanthidium in flowing waters of the Appalachian Mountains (North America): Ecology, distribution and taxonomic notes. Limnologica, 37, 227-241.

Potapova M.G., Charles D.F., Ponader K.C. and Winter D.M., 2004. Quantifying species indicator values for trophic diatom indices: a comparison of approaches. Hydrobiologia, 517, 25-41.

Poulickova A., Vesela J., Neustupa J. and Skaloud P., 2010. Pseudocryptic Diversity versus Cosmopolitanism in Diatoms: a Case Study on Navicula cryptocephala Kutz. (Bacillariophyceae) and Morphologically Similar Taxa. Protist, 161, 353-369.

Pringle C.M., 1990. Nutrient spatial heterogeneity: effects on community structure, physiognomy, and diversity of stream algae. Ecology, 71, 905-920.

Rimet F., 2012. Recent views on river pollution and diatoms. Hydrobiologia, 683, 1-24.

Rimet F. and Bouchez A., 2011. Use of diatom life-forms and ecological guilds to assess pesticide contamination in rivers: lotic mesocosm approaches. Ecol. Indic., 11, 489-499.

Rimet F. and Bouchez A., 2012. Biomonitoring River Diatoms: Implications of Taxonomic Resolution. Ecol. Indic., 15, 92-99.

Round F.E., Crawford R.M. and Mann D.G., 1990. The diatoms, Biology, morphology of the genera, Cambridge University Press, $747 \mathrm{p}$.

Rumeau, A. and Coste M., 1988. Initiation à la systematique des diatomées d'eau douce pour l'utilisation pratique d'un indice diatomique générique. Bull. Fr. Pêche Piscic., 309, 1-69.

Smol J.P. and Stoermer E.F., 2010. Applications and uses of diatoms: prologue. In: Smol J.P. and Stoermer E.F. (eds.), The diatoms: applications for the environmental and earth sciences, 2nd edition, Cambridge University Press, 3-7.

Trobajo R., Clavero E., Chepurnov V., Sabbe K., Mann D.G., Ishihara S. and Cox E.J., 2009. Morphological, genetic and mating diversity within the widespread bioindicator Nitzschia palea (Bacillariophyceae). Phycologia, 48, 443-459.

Tudesque L., Grenouillet G., Gevrey M., Khazraie K. and Brosse S., 2012. Influence of small-scale gold mining on French Guiana streams: Are diatom assemblages valid disturbance sensors? Ecol. Indic., 14, 100-106.

Tuji A., 2000. Observation of developmental processes in loosely attached diatom (Bacillariophyceae) communities. Phycol. Res., 48, 75-84.

Van Heurck H., 1882. Synopsis des diatomées de Belgique, Anvers 1885.

Vanelslander B., Creach V., Vanormelingen P., Ernst A., Chepurnov V.A., Sahan E., Muyzer G., Stal L.J., Vyverman W. and Sabbe K., 2009. Ecological differentiation between sympatric pseudocryptic species in the estuarine benthic diatom Navicula Phyllepta (Bacillariophyceae) 1. J. Phycol., 45, 1278-1289.

Weaver W. and Shannon C.E., 1949. The Mathematical Theory of Communication, University of Illinois Press, Urbana.

Zampella R.A., Laidig K.J. and Lowe R.L., 2007. Distribution of the diatoms in relation to land use and $\mathrm{pH}$ in blackwater coastal plain streams. Environ. Mange., 39, 369-384.

Zelinka M. and Marvan P., 1961. Zur Prazisierung der biologischen Klassifikation der Reinheit fliessender Gewasser. Arch. Hydrobiol., 57, 389-407. 